\title{
Redefining the Lexicon of Power, Envisioning the Future: The Atikamekw Nehirowisiw Nation and the Comprehensive Land Claims Negotiations
}

\author{
Benoit Éthier Université du Québec en Abitibi-Témiscamingue \\ Gérald Ottawa Conseil de la Nation Atikamekw \\ Christian Coocoo Conseil de la Nation Atikamekw
}

\begin{abstract}
Treaties and land claims negotiations between state institutions and Indigenous Peoples are necessarily tied to issues of territorial entanglements, resistance and coexistence. Regularly, studies of these negotiation dynamics make explicit the articulation and differentiation of Indigenous "life projects," referring to the embodiment of socio-cultural desires, visions, aspirations and purposes - vis-à-vis neoliberal development projects. This article focuses precisely on the dynamics of negotiation in which the Atikamekw Nehirowisiwok (north-central Quebec) and state institutions have been involved for the last 40 years under the Comprehensive Land Claims Policy. More specifically, it addresses different policy mechanisms such as the extinguishment policy, burden of proof, debt obligations and results-based approach that are part and parcel of the negotiation process. Without disregarding the unequal power relations, this article also presents the motivations and aspirations expressed by the Atikamekw Nehirowisiwok in the negotiation process. It explains how their engagements are mobilised into nehirowisiw orocowewin - that is, a larger and deeper political and cultural project relating to the affirmation of nehirowisiw miro pimatisiwin, an Indigenous way of life and living well that is tied to the maintenance of a creative and open-ended coexistence based on reciprocity, complementarity, autonomy and consensus.
\end{abstract}

Keywords: Comprehensive Land Claims Policy, Indigenous legal order, Indigenous knowledge, Atikamekw Nehirowisiw, Canada

Resumé : Les processus de négociation des traités et des revendications territoriales entre les institutions étatiques et les peuples autochtones renvoient nécessairement à des questions de territorialités enchevêtrées, de résistance, et de coexistence. Bien souvent, les études portant sur ces processus de négociation explicitent l'articulation et la différenciation entre les «projets de vie » autochtones - en tant qu'incarnation de désirs, de visions, d'aspirations et d'objectifs socioculturels - et les projets de développement néolibéraux. Cet article traite spécifiquement du processus de négociation auquel participent depuis 40 ans les Atikamekw Nehirowisiwok (centre-nord du Québec) et les institutions étatiques dans le cadre de la Politique des revendications territoriales globales. Plus précisément, il explore différents mécanismes politiques, dont la " clause d'extinction ", le " fardeau de la preuve ", "l'obligation de dette » et « l'approche axée sur les résultats », qui font partie intégrante du processus de négociation. En outre, sans négliger les rapports de force inégaux, l'article présente les motivations et les aspirations exprimées par les Atikamekw Nehirowisiwok au sein de ce processus de négociation. Il montre comment leurs engagements sont mobilisés dans le nehirowisiw orocowewin, un projet politique et culturel plus vaste et plus profond lié à l'affirmation du nehirowisiw miro pimatisiwin, lequel consiste en un mode de vie et de bien vivre autochtone associé au maintien d'une coexistence créative et ouverte, fondée sur la réciprocité, la complémentarité, l'autonomie et le consensus.

Mots clés : politique des revendications territoriales globales, ordre juridique autochtone, savoirs autochtones, Atikamekw Nehirowisiw, Canada

\section{Introduction}

7 reaties and land claims negotiations between state $\mathcal{L}$ institutions and Indigenous Peoples are necessarily tied to questions of territorial entanglements, resistance, coexistence and dialogue. In the context of comprehensive land claims, Indigenous Peoples must formulate their rights in political and legal but also epistemological and ontological languages and modes imposed by state law. For example, they must articulate their territorial claims with the concept of territorial private property as understood by state law, a concept that does not adequately represent the relationships that members of different Indigenous nations have with their territory that promote flexible borders (Nadasdy 2012; Thom 2014). The ontological and epistemological principles on which Atikamekw Nehirowisiwok's (north-central Quebec) normative practices and processes are based may appear to be incompatible with state legal principles and categories. In fact, these legal and normative principles, practices, categories and processes are articulated in complex dynamics of assimilation, appropriation, "indigenisation" and differentiation (Blaser 2004; Clammer, Poirier and Schwimmer 2004; Poirier 2004, 2010, 2017; 
Sahlins 1999). Negotiations between states and Indigenous Peoples contribute to defining and making more explicit the differences between these normative systems and these complex socio-political dynamics.

This article provides a critical perspective on the Canadian Comprehensive Land Claims Policy. More specifically, it addresses different mechanisms of the policy such as the extinguishment policy, legal certainty and the burden of proof, which are part and parcel of the negotiation process. Without disregarding the unequal power relations, the text also presents the approaches, strategies, desires and visions that the Atikamekw Nehirowisiwok have conceived and put into practice in the context of the land claims negotiations with federal and provincial governments in which they have been engaged since $1979 .{ }^{1}$ In their ongoing negotiations with state institutions, the Atikamekw Nehirowisiwok ${ }^{2}$ are far from passive subjects. In response to the gradual invasion of their territory by non-Indigenous activities and interests, they have been working for decades to implement their own societal and life projects (Blaser 2004) and to develop common strategies of creative resistance (Éthier 2017; Poirier 2010, 2017; Sahlins 1999) that focus on both the progressive transformation of power relations and the state's recognition of their system of territorial authority and sovereignty. Atikamekw Nehirowisiwok work hard to maintain their own political and decision-making instruments with respect to family hunting territories. For example, they elaborate various mechanisms to give Elders and territorial leaders ( $k a$ nikaniwitcik) an important voice in political decision making with regard to community activities taking place within family hunting territories (Éthier 2017; Éthier and Poirier 2018; Houde 2011, 2014; Poirier 2017).

Throughout the comprehensive land claims process, the Atikamekw Nehirowisiwok have redesigned their strategy and the terms by which they define themselves in their relationship with the state. The lexicons and the practices of translation of the terms the Conseil de la Nation Atikamekw Nehirowisiw (CNA) uses in the negotiation and consultation processes can provide some clues to understanding a change of attitude by the Indigenous counterparts. As will be mentioned in this article, this lexical change illustrates the shift from a perception of paternalistic power relations to an attitude of cultural and political affirmation. The Atikamekw Nehirowisiwok's current mobilisation around their rights to self-determination aims to "put things in the right place" (nahitatowin), which means practising their own values and life projects without having to justify themselves to state institutions, and ensuring an equal and genuine dialogue between Indigenous and state institutions. In the context of the comprehensive land claims negotiation, Atikamekw Nehirowisiwok ensure the application and respect of certain fundamental practices and values related, for example, to consensual decision making, to the autonomy and reciprocity between persons and families, and to the transmission of territorial knowledge, rights and responsibilities. Finally, in relation to Tully's (2016) concept of genuine dialogue, we want to explore how the principles of consensus and complementarity intended in the Atikamekw Nehirowisiw's system of territorial authority and customary law can help us to rethink dialogue and land claims negotiations in a more egalitarian way.

\section{Nehirowisiw Otiperitamowin: Power, Rights and Responsibilities}

The Atikamekw Nehirowisiw nation is composed of approximately 7,000 members who live mostly within three communities - Wemotaci, Manawan and Opitciwan - all located in Haute-Mauricie, in north-central Quebec. Over the past few decades, the Atikamekw Nehirowisiwok, like other First Nations in Canada, have been involved in self-determination and land claims negotiations for the recognition of their rights, including their own political and territorial customary practices. However, unlike other First Nations such as the James Bay Cree or the Nisga'a of the Canadian West Coast, the Atikamekw Nehirowisiwok have not so far signed any treaty, historical or modern, with the federal or provincial governments. Since the 1980s and despite the usual political, but also ontological and epistemological, obstacles, the Atikamekw Nehirowisiwok remain hopeful that their own visions, aspirations and epistemological principles will eventually be recognised. Their efforts are mobilised concretely through daily practices, including relationships to family territories and hunting activities, as well as through their manifold engagements concerning land claims negotiations.

For the Atikamekw Nehirowisiwok hunters, the occupation and use of their ancestral territories ensure the transmission of territorial knowledge, as well as forms of territorial authority and sovereignty, namely, tiperitamowin aski. The expression tiperitamowin aski refers to a form of relationship that includes specific rights and responsibilities toward the territory. In this sense, the Atikamekw Nehirowisiwok use this concept to put forward their legal relationship to the territory. The term nehirowisiw otiperitamowin can therefore be translated as "self-responsibility," "sovereignty" or "personal autonomy." Nehirowisiw otiperitamowin is intrinsically linked to the conceptual triad of power, rights and responsibility. 
Atikamekw Nehirowisiwok's hunting practices, land occupation, and transmission of family and territorial knowledge are the expressions of their territorial rights and responsibilities. Since the 1980s, members of the three communities and the CNA have developed several initiatives to promote the occupation and use of family hunting territories. ${ }^{3}$ For example, in recent years, members of the Atikamekw Nehirowisiw communities have carried out efforts to transmit to younger generations the knowledge and experiences related to the use of ancestral trails (mohonan and moteskano), portage sites (onikam) and campsites. Mohonan are ancestral canoe routes and moteskano are ancestral winter trails. These terms cannot simply be translated as "trails" (meskanaw) because they refer to an action performed by the ancestors within dwelling places (Éthier and Poirier 2018).

For example, each year since 2014, in February and March, members of the community of Opitciwan participate in the Moteskano project, ${ }^{4}$ which takes place on ancestral winter trails in family hunting territories around the Gouin Reservoir. ${ }^{5}$ The Moteskano project takes place over a period of about two weeks and brings together more than 30 walkers of different ages (between 15 and 70 years old) from the community. It should be noted that a significant part of the community's members - men and women - are involved in this activity (trail itinerary and maintenance, equipment preparation, fabrication of snowshoes, moccasins, cooking and so on). ${ }^{6}$

In preparing the Moteskano project, family members gather during the summer and fall to decide, with the help of the Elders, which route to take. The Elders share their knowledge and stories related to the moteskano on their hunting territory, also taking into account the transformations to the land through forestry activities, the construction of dams for hydroelectric projects and so forth. Other initiatives, similar to the Moteskano project, are being organised jointly by members of the three communities (Manawan, Wemotaci and Opitciwan). This is the case for the Tapiskwan project, ${ }^{7}$ which has been organised every summer since 2015. The Tapiskwan project aims to transmit knowledge related to mohonan (or canoe routes) and portage sites used and passed down by ancestors. During the Tapiskwan project, members of the nation are invited to navigate, by canoe, a portion of the Tapiskwan sipi watershed (Saint-Maurice River) between Opitciwan and the communities of Wemotaci and Manawan. ${ }^{8}$ As part of the Tapiskwan project, families in each community are responsible for mapping canoe routes, portages and campsites. Elders play an important role in sharing their knowledge about mohonan and onikam. The $k a$ nikaniwitcik (territorial leaders) are also involved and consulted for routes and for access to their family hunting territory and campsites. Meetings are held in each of the communities to share family knowledge in relation to mohonan and onikam in order to map out the appropriate route and ensure respect for dwelling places.

The goal of these collective projects to reconnect with mohonan and moteskano go beyond preserving and transmitting families' knowledge of the routes, portage sites and campsites. They encourage families to live these experiences of nomadic life within notcimik (the forestland) as was practised by their ancestors (kimocomonowok). Travelling through family hunting territories promotes an intimate experience within notcimik, a forestland shaped by the ancestors. An entire process of individual and collective healing, self-identification and territorial affirmation is significant to these experiences and collective projects. These intergenerational relationships to notcimik are described by members of the nation and participants of these two projects as essential to maintaining social balance and to nehirowisiw opimatisiwin, a philosophy of existence based on a relational ontology (Poirier 2013; Scott 2017). Nehirowisiw opimatisiwin refers to life and its cycles, to a mode of existence and coexistence that includes ancestors and generations to come (Éthier 2017). The following quote from a Manawan Elder, collected by Poirier and Niquay in the late 1990s, can help us understand the essence of this multi-temporal relationship to life: "When you hear laughter or hear hits on the trees, what you feel are the things from the past, it comes from the past. It's either the past or the future. If it's the future, the land will still exist for a long time to come. When I hear this noise, it makes me happy" (Poirier and Niquay 1997-99; author's translation).

Initiatives related to mohonan and moteskano (the ancestral trails) encourage the transmission of existential values, practices and ancestral knowledge involving a set of rules, rights and responsibilities. The concept of nehirowisiw otiperitamowin refers to power and autonomy and is closely linked to the concept of territorial responsibility (tiperitamowin aski). In this sense, the continuity of territorial practices and transmission of ancestral values and visions can also be described as the expression of a creative resistance in the sense that they are collectively and differently defined by the members of the nation. It is also a form of creative resistance inasmuch as those practices, values and visions are mobilised directly and concretely in the dynamics of negotiation with state institutions and non-Indigenous actors (Ortner 1995; Poirier 2000). This is the case, for example, in the negotiation processes conducted by the 
Atikamekw Nehirowisiwok with the governments of Canada and Quebec in the context of the Comprehensive Land Claims Policy.

\section{The Comprehensive Land Claims Policy}

Following the Calder case (Calder v British Columbia 1973), the Canadian government implemented the Comprehensive Land Claims Policy (CLCP) with the objective of negotiating trilateral agreements, also known as modern treaties, with Indigenous and provincial/ territorial governments. The main goal of these so-called modern treaties is to assert the Canadian government's sovereignty over territories in order to extinguish Aboriginal title (Asch [1998] 2008; Charest 2001, 2017; Cleary 1993; Dupuis 1993, 1997; Samson 1999). This objective is expressed in the clause of legal certainty of the title of the state's sovereignty and in the extinguishment policy for Aboriginal title. Although the CLCP has been updated since 1973 (in 1986 and 2014), these clauses remain at the centre of the policy. ${ }^{9}$ According to Indigenous and Northern Affairs Canada, ${ }^{10}$ these clauses were designed to ensure an appropriate climate for economic development based on the exploitation of natural resources, which is expected to benefit all Canadians (Charest 2001; CIRNAC 2014a; Harris 2004; Samson 2016). It is important to note here that Justin Trudeau's federal government (2015-) committed to a renewed policy through consultation with First Nations people. This renewed policy could represent advances in various aspects of the current policy, including setting aside the extinguishment clause (CIRNAC 2014a). However, as of August 2019, a few weeks before the federal election (October 2019), this policy had not yet been renewed.

Another objective of this policy is to reach out-ofcourt agreements, thus reducing the costs associated with legal processes and avoiding the risk of losing cases. Like the Numbered Treaties signed between the government of Canada and Indigenous nations between 1871 and 1921, modern treaties include monetary compensation as well as some property and traditional practices rights in some parts of the Indigenous nations' ancestral territories. In addition, modern treaties provide legal clarification on a much broader range of issues, such as rights to use some territories and law-making authority in certain areas, specific rights to natural resources, benefit agreements for resource development projects, and the creation of local Indigenous organisations (Charest 1992, 2001, 2017; Grammond 2013).

In 1975, two years after the implementation of the CLCP, members of the Atikamekw Nehirowisiw and Innu (Montagnais) nations put their efforts and resources together to create their own political organisation, the
Conseil Atikamekw-Montagnais (CAM), whose main mission was, until its dissolution in 1994, to promote and defend the rights of its members and to act as political representatives vis-à-vis their state interlocutors. In 1979, the CAM initiated the process of comprehensive land claims and adopted a resolution to take charge of all the programs and services currently provided by Indian Affairs and/or other federal and provincial agencies (CAM 1979; Charest 1992). All the efforts of these First Nations were aimed at gaining more power in the management of their lives and their territory.

In 1983, the Atikamekw Nehirowisiwok created their own political organisation, the Conseil de la Nation Atikamekw Nehirowisiw (CNA), whose administrative committee is composed of the three band chiefs, an elected president/grand chief and a general director. This political authority is a national initiative and therefore does not fall under the Indian Act, unlike band councils. In a process of decolonisation, recognition and self-determination ("sovereignty"), the CNA has, since its creation, been conducting research and consultation projects aimed at documenting and recognising Atikamekw Nehirowisiwok institutions: systems of authority and customary law that should, it argues, be applied to all activities taking place within nitaskinan, the claimed ancestral territory. One of the main mandates of the CNA is to act as an interlocutor in the comprehensive land claims negotiations conducted by the Atikamekw Nehirowisiwok with the governments of Canada and Quebec (CNA 2012).

\section{Bill C-9 and the Extinguishment of Indigenous Title}

Issues of overlapping claims and the extinguishment of the Aboriginal titles resulting from signing historical or modern treaties are unavoidable matters in Indigenous land claims negotiations in Canada. Indeed, the signing of the James Bay Agreement (1975) and the Northeastern Quebec Agreement (JBNQA) (1978) by the Eeyouch/ Eenouch (Cree), ${ }_{11}^{11}$ Naskapi and Inuit had the effect of extinguishing Aboriginal title within the boundaries of the agreement territories (Bill C-9). ${ }^{12}$ Like the Innu and the Anicinabek, the Atikamekw Nehirowisiwok claim a part of the territory from which the Aboriginal title has been extinguished. Those First Nations and their respective organisations were never consulted, were never invited to the negotiating table, and thus never signed this agreement. Furthermore, they received no compensation for the extinction of their Aboriginal title over this part of their ancestral territory.

The issue of the extinguishment of Aboriginal title caused by Bill C-9 of the James Bay Agreement has been 
back in the news in recent years with the mobilisation of representatives of the Innu, Atikamekw Nehirowisiw and Anicinabe nations, all affected by the extinguishment of Aboriginal title in the territory covered by the Bill C-9. Following a meeting in Mashteuiatsh in October 2014, representatives of Atikamekw Nehirowisiw, Innu and Anicinabe nations decided to form a coalition to coordinate their strategy.

On 13 November 2014, the Atikamekw Nehirowisiw, Innu and Anicinabe coalition held a press conference in Montreal to contest the extinguishment of their Aboriginal title in those parts of their respective territories covered by the James Bay Agreement. At the press conference, members of the coalition made it clear that they intended to take legal action against the Canadian and Quebec governments. The members of this coalition specified that their intention was not to reverse the treaty but to have the extinguishment clause recognised as inapplicable to non-signatory First Nations.

The claim made by the Atikamekw Nehirowisiwok and the coalition members do not directly target the Cree (Eeyouch/Eenouch) and the Inuit who are signatories of the agreement, but it is clear that it is the extinguishment clause of the Aboriginal title contained in the JBNQA that is the source of the problem. The coalition members are well aware that the vision of private property and territorial categorisation and delimitation included in the JBNQA is not representative of the vision of the majority of the Eeyouch/Eenouch. Several Atikamekw Nehirowisiwok families, mostly from Opiticwan, who share territories with Eeyouch families say that, on the ground, they have a good relationship with them and do not take the territorial frontiers set by the treaty in consideration. Rather, they do as they have always done: they respect the autonomy of the hunters' families and maintain reciprocal relationships with them. In practice, Eeyouch and Atikamekw Nehirowisiwok families negotiate their territorial use and occupation on the basis of their own normative systems and according to the needs of their families. The concepts of "fixed borders" and "private property" as defined by state law, even if they are used in the context of land claim negotiations, are not the most appropriate to account for the legal, political, social and economic dimensions of land within Algonquian nations today (for other First Nations, see also Nadasdy 2012; Thom 2014; and this issue). The concepts of relational territoriality and territorial sharing, involving dynamics of reciprocity, autonomy and territorial responsibilities, better reflect the types of relationships between families and neighbouring Indigenous groups (Poirier 2017; Vincent 2016). Christian Awashish, chief of the band of Opitciwan, said at the coalition's press conference (Montreal 2014), "By virtue of the declaration that unites us, we [members of the coalition] affirm that we want to settle the territorial sharing by reaffirming that the principle of borders has never been a concept used by the Elders and we intend to respect this heritage" (Atikamekw Nehirowisiw, Innu and Anicinabe Coalition 2014; author's translation).

In practice, the problem of the extinguishment of Aboriginal title on shared territory arises mainly when development projects, such as mining or forestry projects, take place on territories affecting Eeyouch, Atikamekw Nehirowisiw, Innu or Anicinabe family activities, territorial responsibilities and knowledge transmission.

Again, in the words of Christian Awashish at the press conference,

[The governments of Canada and Quebec impose] the rules of the game with the agreement [JBNQA] ... We are just spectators. We suffer the damage done to the ancestral territory. Families report it to us continuously. What can we do to stop that? There is no political will [from the federal and provincial governments]. Are we going to court? Is it really the court that will give us moral, political and legal assistance? This is really an unfair situation. (Atikamekw Nehirowisiw, Innu and Anicinabe Coalition 2014; author's translation)

Third parties and non-Indigenous actors with private interests tied to the exploitation of resources in this part of the agreement territory have rights and obligations that are affirmed by the James Bay Agreement but have no obligation to consult the members of the Atikamekw Nehirowisiw, Innu and Anicinabe nations, since their ancestral title to the territory was extinguished by the treaty. As a lawyer pointed out during a consultation session held in Opitciwan (October 2014), Bill C-9 extinguishes Aboriginal title for non-signatories but does not extinguish territorial rights for non-Native peoples. This means that, unlike Atikamekw Nehirowisiwok, non-Indigenous actors do not lose any territorial rights with this agreement. In this regard, for the members of the coalition, Bill C-9 is discriminatory and incompatible with the Canadian Charter of Rights and Freedoms and the United Nations' Universal Declaration of Human Rights, which guarantee equal rights. The use of this argument to challenge Bill C-9 is an option for the coalition members who are still thinking about taking legal action (Sioui 2014; St-Pierre 2014).

\section{The Burden of Proof and Debt Obligations}

Within the process of comprehensive land claim negotiations, Indigenous Peoples have the burden of proof, 
meaning that they have the duty to prove that they are the potential holders of non-extinguished Aboriginal titles and rights. Indigenous organisations must, among other things, prove their sustained and exclusive occupation of the territory claimed prior to the sovereignty of the Canadian state and the continuity of traditional practices on their ancestral territory (Charest 2001; Dupuis 1997; Grammond 2013). Instead of rethinking and reviewing the relevance of the concept of exclusive property rights, the Canadian government suggests that Indigenous nations with overlapping claims (claims to land rights in the same parts of the territory) negotiate an overlap resolution boundary among themselves (Nadasdy 2012, 2018). It is obvious that, during this negotiation process, the various levels of government are compelling the Indigenous nations present at the negotiating table to frame their claims within fairly narrow boundaries, constraining them to appropriate and use discursive strategies related to ethno-territorial state nationalism (Nadasdy 2012, 2018; Sletto 2009; Thom 2009, 2014, 2015).

As noted, this obligation to prove exclusive occupation is problematic in that it does not take into account the principle of territorial and resource sharing that is fundamental to many Indigenous nations in Canada (Charest 2001; Nadasdy 2012; Thom 2014). The principle of territorial and resource sharing for people in need takes precedence over any principle of ownership and territorial boundaries, at least for Algonquian groups (Éthier 2017; Feit 2004; Poirier and Niquay 1997-99; Vincent 2016). This principle is at the core of Indigenous relational territoriality and shared territory.

To demonstrate the existence of their ancestral title, Indigenous groups must provide expert knowledge to produce admissible proof of both the exclusive occupation and use of their ancestral territory (Charest 2001; CNA 1996; Grammond 2013). Producing such proof mobilises significant human and economic resources, and the majority of Indigenous communities and nations do not have sufficient financial and human resources to meet the federal and provincial governments' requirements. Before the tabling of the 2019 budget, the federal government provided loans to Indigenous groups who were engaged in the CLCP. When an agreement was finally signed, the amount of the loans was deducted from the compensation amount negotiated in the agreement. Debt obligation resulting from these loans was a mechanism for the federal government to grant itself additional power in these negotiations. The Indigenous groups were caught in a perpetual cycle of debts orchestrated by their counterparts at the negotiating table. For the Atikamekw Nehirowisiw nation and its members, the debt accumulated during the process of land claim negotiations is described as pernicious. While this First Nation was accumulating debts from the federal government to finance the production of proof of their occupation and use of their ancestral territory, the provincial government was accumulating, on that same territory, royalties related to the exploitation of natural resources by private industries. As a former councillor of the Wemotaci Band Council pointed out at a territorial conference organised by the CNA (2014):

\section{In the negotiations, we accumulated $\$ 32$ million in debt. ${ }^{13}$ The [Quebec] government receives $\$ 53$ million every year from hunting. How much money does Hydro-Québec withdraw from [ancestral Atikamekw Nehirowisiw] territory? How much does the Quebec government get from resort leases in our territory? And the government loans us money so we can meet with them? (author's translation)}

The control mechanism resulting from debt obligations changed with the 2019 federal budget. Recognising that debt obligations were becoming prohibitive to the economic development of communities, Justin Trudeau's Liberal government committed to forgiving loans related to the CLCP and reimbursing Indigenous governments that had already repaid these loans. In some instances, the federal government replaced them with non-repayable contributions (Government of Canada 2019). It is important to note that this financial commitment by the current federal government to forgive loans extends over at least seven years (Government of Canada 2019). For the moment, not all debts have been forgiven (Belrichard 2019). This is the case for the Atikamekw Nehirowisiw nation, which remains indebted. It is important to ensure that this approach is applied and extended in the coming years to all Indigenous nations involved in the CLCP.

\section{The Results-Based Approach}

Since 2012, Stephen Harper's Conservative federal government had been promoting a results-based approach to accelerate the negotiation process and ensure that agreements would be completed as quickly as possible. One objective of the federal government's results-based approach was to address the debt accumulated by Indigenous groups engaged in land claims negotiations (CIRNAC 2014b, n.d.). ${ }^{14}$ With this approach, the federal government allowed itself to identify the negotiation projects that seemed close to reaching an agreement and to set aside other negotiation projects that it considered, according to its own criteria, difficult to achieve (CIRNAC 2014b, n.d.). The progress of the targeted negotiation projects is evaluated by the government on a yearly basis. 
The objectives of this approach are to accelerate the negotiation process and to reduce the costs associated with territorial negotiations. With this approach, the federal and provincial governments maintain significant power in the negotiations by selecting their interlocutors, imposing ultimatums and brandishing the constant threat of ending negotiations if the (indebted) Indigenous organisations refuse the proposed terms of the agreement.

The complexity of these agreements and the fact that they are often negotiated by a small number of Indigenous representatives have caused some researchers and Indigenous Peoples to describe the results-based approach as anti-democratic. For example, in the case of the Labrador Innu agreement in principle signed by the Newfoundland and Canadian governments, Samson (2016) notes that in the referendum on the agreement, the Innu government gave $\$ 5,000$ to each voter to encourage them to vote, even if they had very limited access to the contents of the agreement and did not participate directly in its formulation. In this example, the money given to the voters following the referendum came from the loan granted by the Canadian government as part of the CLCP (Samson 2016). It was an advance payment on the compensation to be received by the Indigenous organisation following the treaty's signing. This strategy is questionable, as negotiators use the Indigenous community's loans and indebtedness to "buy" the vote and repay themselves. Here, the question is not of impugning motives to the members of this negotiating table but rather of presenting some mechanisms of power maintained within the CLCP.

Even though the agreement was voted on through a referendum by members of the Indigenous communities or nations, those members did not have access to all the relevant information needed to make an informed decision (Samson 2016). ${ }^{15}$ The results-based approach has been criticised by many Indigenous Peoples involved in comprehensive land claims because it is not respectful of local values and systems of authority (Charest 2017; Samson 2016). As we will see below, this approach does not align with the consensual decision making and mode of transmission of territorial authority and responsibility, which are at the core of the Atikamekw Nehirowisiw's political knowledge and practice.

\section{Natokiskeritamowin: Sharing Knowledge Together}

Given the unequal power relations and the risks involved with negotiations, why do Indigenous Peoples devote so much energy and resources toward comprehensive land claims negotiations and similar mechanisms? This is not a new question; it is one regularly raised by researchers working in Indigenous contexts in Canada, Australia and elsewhere (Pasternak 2017; Povinelli 2002; Samson 1999, 2016). These issues are also regularly brought up by Indigenous Peoples, such as the Atikamekw Nehirowisiw, who consciously, and not without scepticism, choose to risk engaging on this path in their own way. As part of its strategy for decolonisation, recognition and selfdetermination, the CNA has been carrying out research and consultations since the early 1980s to document Atikamekw Nehirowisiw traditional institutions, systems of authority and customary law that should, it argues, be applied to all activities taking place within nitaskinan, the claimed ancestral territory.

Throughout the negotiation process, the CAM and later the CNA have carried out important work, such as the CAMROUT (Conseil Atikamekw-Montagnais, recherche sur l'occupation et l'utilisation du territoire) project (also known as La Grande Recherche), documenting territorial knowledge, as well as the occupation and use of the claimed ancestral territories (Brassard and Castonguay 1983; Castonguay 1983; Charest 1992, 2001; Dandenault 1983; Léger 1983). The CAM and the CNA have also created various organisations and associations to further this research and to disseminate information to its members. These include, for example, the creation in 1980 of the Sociéte de communication Atikame$\mathrm{kw}$-Montagnais (SOCAM), whose role is to disseminate, on a daily basis, a wide range of information related to Indigenous political issues to all Innu and Atikamekw Nehirowisiw communities (Charest 1992). SOCAM runs a radio station that promotes the transmission of ancestral knowledge through the participation of Elders, the transmission of the Innu and Atikamewk Nehirowisiw languages (most of the radio programs are produced in these languages), and the dissemination and promotion of Innu and Nehirowisiw music, which forms a signification portion of the station's music programs.

The CNA also created the Association Mamo Atoskewin Atikamekw (AMAA), which operated between 1990 and 1996. The AMAA developed a number of research studies about Atikamekw Nehirowisiw management practices and territorial knowledge related to moose yards, place names, behaviours and characteristics of animals and plants, and more. The work carried out by the AMAA and CAMROUT is still being used, discussed and updated today in different consultation processes. In particular, their work on territorial knowledge still guides the different symposia organised by the CNA. These symposia provide an opportunity to consult with members of the nation on territorial negotiations. Ultimately, this process aims to create a self-governing Atikamekw Nehirowisiw government, but my analysis 
shows that the political process and life projects achieved by the Atikamekw Nehirowisiwok in recent decades, in themselves, exemplify self-determination and creative resistance (Éthier 2017).

The approach used by Atikamekw Nehirowisiw nation members in dealing with the land claims negotiations process seems to be in accordance with an internal policy of consensus and in keeping with their own mode of transmitting knowledge, powers and territorial authorities. Members of the Atikamekw Nehirowisiw nation ensure that large-scale political decisions, such as the creation of an Indigenous government, are taken collectively. Throughout the process of land claims negotiation, the Atikamekw Nehirowisiwok have organised several territorial symposia to broadly discuss the knowledge and territorial management models they wish to have recognised by state institutions and non-Indigenous civil society actors claiming interests within nitaskinan. These symposia provide an important venue for the sharing of family knowledge, narratives and experiences concerning territorial relations and negotiations (Éthier 2017). The territorial symposia are recorded and disseminated to the three communities and to members living outside the communities by radio stations and SOCAM. Members of the nation have access to this information and may participate in the process directly or through a family representative. The whole process allows the members to share experiences and knowledge and to envision a societal project, such as the creation of an Atikamekw Nehirowisiw government based on the values and normative principles held by Elders and territorial leaders.

In nehiromowin (the language of the Atikamekw Nehirowisiwok), the term natokiskeritamowin is used to announce a consultation that brings together a diversity of perspectives, knowledge and experiences. The term natokiskeritamowin could be translated as "sharing knowledge together" or the "inventory of knowledge." In the consultations that take place at the territorial symposia, the Atikamekw Nehirowisiwok demonstrate an inclination toward consensus-based decision making that respects the diversity of perspectives and experiences, as well as the autonomy of each person to develop their own experiences and visions. The important thing in all of these consultative processes conducted by the Atikamekw Nehirowisiwok is not so much to achieve a single vision but to provide a space to share a plurality of knowledges and experiences. They are also opportunities to recall the terms and visions passed on by the Elders and territorial leaders in order to ensure cohesion between past, present and future actions, consistent with the visions, values and practices of the ancestors.
According to different Elders from the three communities of Atikamekw Nehirowisiwok consulted during Éthier's doctoral study (2012-17), the narratives shared by their ancestors ensure the transmission of normative knowledge related to Atikamekw Nehirowisiw ways of life. Transmission of knowledge through oral tradition is also very much alive and part of the local systems of authority. Elders choose how, when and to whom they pass on knowledge and stories. They do not transmit all their knowledge to a single person. They will share specific knowledge with specific people, usually people to whom they have also transferred part of their territorial responsibilities. This mode of knowledge transmission is linked to the deeply held values of social cohesion and fair distribution of knowledge, powers, rights and responsibilities. These powers, rights and responsibilities are regularly transmitted within families and are directly tied to knowledge developed and transmitted within their hunting territories (atoske aski, natoho aski). The idea behind this mode of transmission is to bring people and families together so that they can share the Elders' knowledge and experiences. The mobilisation around a societal project (orocowewin), such as the creation of an Indigenous government, is realised through this mode of transmission and through the sharing of individual, familial and collective knowledge and experiences.

It is quite accurate to say that the research and consultation processes carried out by the Atikamekw Nehirowisiwok since 1979 in the context of comprehensive land claims negotiations have been developed to promote political self-determination. However, the nation's members currently agree that these research and consultation processes are actually more useful for facilitating the transmission of territorial knowledge from older to younger generations, who now constitute the majority of the Atikamekw Nehirowisiw nation. A member of the CNA told me recently that "the strength of numbers and the fact that the young generations use the ancestral territory and are taught by our Elders in our language, comfort us and make us confident about the future of our nation" (my translation). The Atikamekw Nehirowisiwok have understood that their future, as a people or as a nation, does not depend solely on the political transformations of the Canadian state, but rather on the commitment of the younger generations and their ability to assert their territorial rights and to practise the territorial and political knowledge transmitted by the ancestors. The entry on the political scene of this new generation of leaders is marked by various mediated actions, including the Declaration of Sovereignty (2014) and the public release of a sign (2016) informing Quebec's 


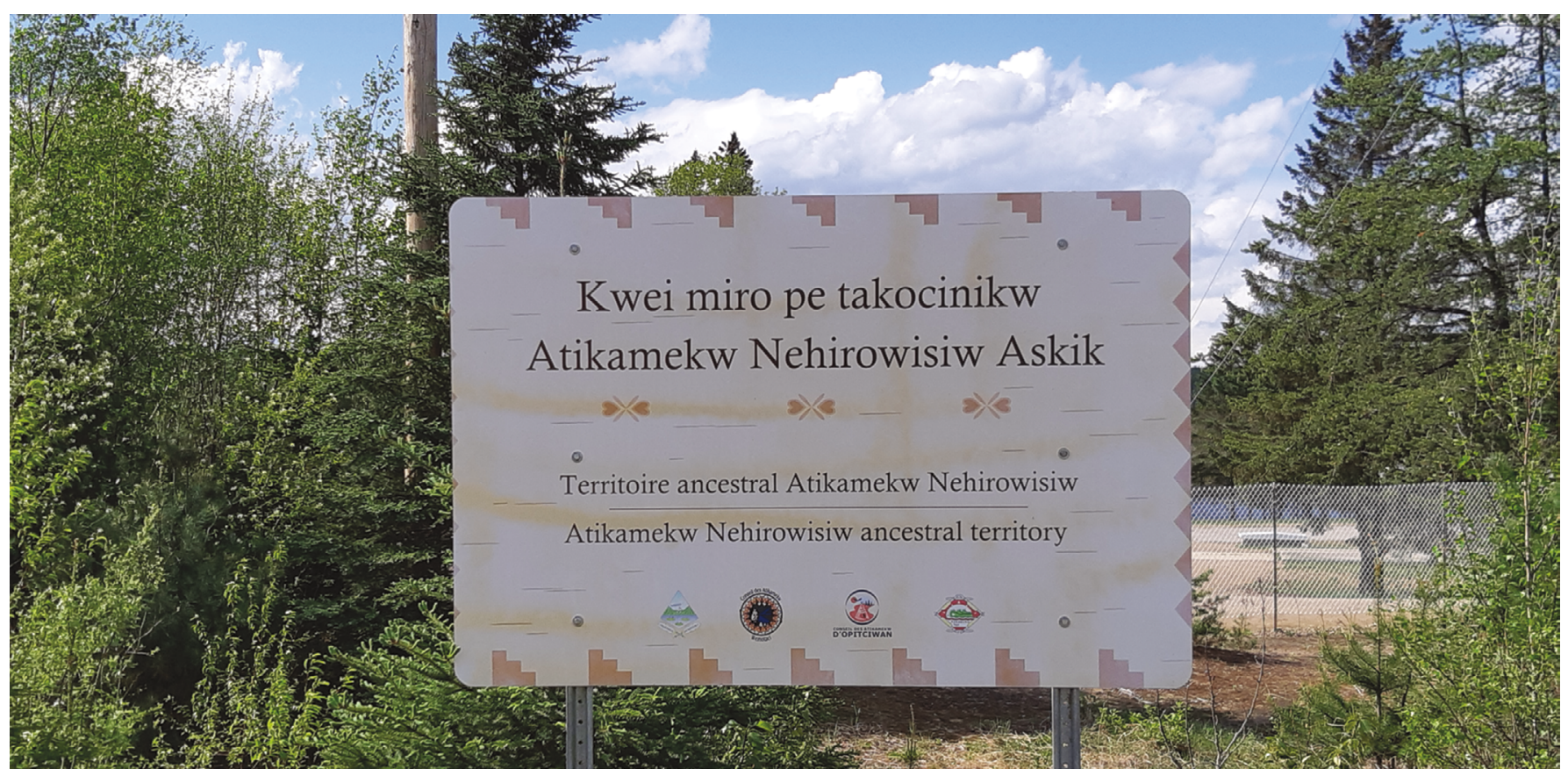

Figure 1: Sign created by the Conseil de la Nation Atikamekw (CNA) and released on 8 September 2016, two years after the Declaration of Sovereignty of Atikamekw Nehirowisiw (8 September 2014).

In 2015, CNA declared 8 September as Atikamekw Nehirowisiw's national day, and actions to assert the rights of self-determination are taken on this date each year since then.

Source: Conseil de la Nation Atikamekw

general population of the ancestral occupation of the territory by the Atikamekw Nehirowisiwok (see Figure 1).

\section{Nahitatowin: "We Put Things in the Right Place"}

In a lexicon developed by members of the nation in the late 1990s in the context of territorial negotiations, the concept of negotiation was translated as ka natipictwatananiwok (CNA 1998), which literally means "to be seated and to approach a standing and immobile person." This term can be used, for example, to describe a child who asks for something from his or her parents. After discussions, members of our working group reassessed the relevance of this term to translate the concept of negotiation because it already assumed an unequal power relationship between the Indigenous (speaker) and the governments of Canada and Quebec (its interlocutors). ${ }^{16}$

To translate the concept of negotiation, working group members suggested instead the use of the term nahitatowin, which means "we put things in the right place." This term better represents the current visions and approaches proposed by working group members concerning territorial negotiations, which must be carried out more as instances of cultural affirmation and less as unequal power relationships. In my analysis, a shift occurred in the Atikamekw Nehirowisiw attitude over the last decades in relation to territorial and political negotiations with state authorities. This shift can be seen in the political strategies deployed by the CNA and the Atikamekw Nehirowisiw members at the negotiating table with the Canadian and Quebec governments. The public consultations, which mobilised Elders and territorial leaders in the consolidation and transmission of territorial knowledge, authorities and responsibilities during the last decades, certainly played a part in this attitude change and drive toward cultural and political affirmation. As we have seen, the Atikamekw Nehirowisiw's way of transmitting knowledge, power and responsibilities is intrinsically linked to principles of consensus and complementarity.

The use of the concept nahitatowin ("we put things in their right place") rather than ka natipictwatananiwok ("to be seated and approaching a standing and immobile person") in the lexicons developed by the CNA illustrates the shift from a perception of paternalistic power relations toward a process of rebalancing dialogue with the state. As James Tully (2016) points out, there are no rules to be prescribed to achieve a "genuine dialogue" that can apply to all contexts of coexistence and negotiation. Here, the mobilisation of Atikamekw 
Nehirowisiw normative conceptions and local systems of authority is essential to the creation and production of an egalitarian and genuine dialogue with the federal and provincial governments. To be achieved, this egalitarian and genuine dialogue must be based on mutual recognition of the modes and potentialities of existence of the parties concerned. This implies the mutual recognition of Indigenous and state normative concepts and knowledge, as well as their articulation. Such mutual recognition must be, I think, a starting point to produce generative, creative and transformative alliances between Indigenous and non-Indigenous peoples.

Canadian jurisprudence demonstrates that law is dynamic and can, to a certain degree, foster the transformation of certain mechanisms of power. Like Indigenous customary laws, Canadian constitutional rights are interpreted contextually from values and principles that are mostly unwritten (Borrows 2010, 2016). John Borrows (2016) reminds us that the western concept of constitution derives from the Latin constituere, which can be translated as "to establish together." According to Borrows, it would be relevant to use this verbal form to better understand the procedural aspect of state law, which is dynamic and in constant negotiation and adjustment. The term constituere suggests an etymology similar to the Atikamekw Nehirowisiw concept of nahitatowin naskamowin. Literally, nahitatowin naskamowin could be translated as "response to our exchanges."

Both concepts, constituere and nahitatowin naskamowin, highlight the processual facets of laws and social relationships. However, these dynamics operate from cultural logics and practices that can sometimes clash. In practice, nahitatowin naskamowin is a political process based on values of social cohesion and consensual decision making. This process is continuous and is adapted to the situational context. The Atikamekw Nehirowisiwok are continuously working on their constitution and societal projects. These activities remain ongoing and adapted to the socio-political contexts of the communities and the Nation. It is therefore not so much the end in itself that is the most important, but the democratic process set in motion in a political practice that is consensual, non-hierarchical and respectful of the diversity of knowledge and experience.

To increase its relevance, the CLCP can and must be revised by attributing a greater place to Indigenous political concepts, knowledge and practices. In his statement to the House of Commons on 14 February 2018, Prime Minister Justin Trudeau promised to launch a process of "engagement" with Indigenous Peoples, provinces and territories to develop a framework for recognising and defining Indigenous rights and to replace the CLCP. This new framework for the recognition of the right to
Indigenous self-determination should have been in place by October 2019 (CIRNAC 2014a). Unfortunately, despite promises, progress has been slow to materialize. In this time of national reconciliation and CLCP renewal, the government of Canada can certainly take advantage of this momentum to change the course of nation-tonation relationships with Indigenous Peoples by including a consensus-based and equitable decision-making approach. Indigenous political principles such as consensus and a balanced redistribution of powers and territorial responsibilities should ultimately respond to two important principles of western democracy: justice and equity. In this regard, the objective of the CLCP and the negotiation practices under it must be established consensually by the Indigenous and state parties. This procedure would give meaning to the term constituere and the principles of equitable sharing of powers, rights and responsibilities.

\section{Conclusion}

After 40 years of negotiations within the CLCP, the Atikamekw Nehirowisiw nation and the governments of Canada and Quebec have not yet found satisfactory common ground for each party. Among the factors that block the negotiations, the extinction clause is a major one; this clause is also unacceptable to the Atikamekw Nehirowisiwok and other First Nations, who are working hard for the recognition of their ancestral title and rights rather than their extinguishment (Asch [1998] 2008; Asch and Zlotkin 2008; Charest 2001; Dupuis 1993). In addition, the fact that Indigenous Peoples have the burden of proof and must demonstrate to their interlocutors at the negotiating table their pre-colonial occupation of the territory within which they practise their "ancestral" activities is also often criticised by some Atikamekw Nehirowisiwok. They wonder why they are the ones having to justify their presence on the territory to the colonial governments, and not the other way around.

The approach taken by the Atikamekw Nehirowisiwok in the context of land claims negotiations can be understood as a societal project with regard to their own philosophies of existence and local systems of authority. As this article has shown, the dynamics of the intertwining of various societal projects are particularly explicit and problematic in the context of comprehensive land claims negotiations. However, some interesting lines of thought emerge directly from the Atikamekw Nehirowisiw's political practices and existential philosophy presented here.

Throughout the comprehensive land claims negotiations and other collective endeavours, the Atikamekw Nehirowisiwok want to ensure the transmission and application of knowledge and responsibilities inherited from their ancestors and to rebalance power relationships with 
state institutions. In these negotiations, the Atikamekw Nehirowisiwok suggest rethinking the process of territorial negotiations to make them consistent with their own philosophies of existence, normative conceptions and system of territorial authority. They want to rebalance power relations between state and Indigenous institutions through these negotiations. Over the last decades, Atikatmekw Nehirowisiw members have changed their attitude regarding territorial and political negotiations with state authorities. This shift, influenced by local initiatives to promote ancestral territorial knowledge and systems of traditional authorities, is manifest in the political lexicon defined by the Indigenous members of the negotiating table and of the Conseil de la Nation Atikamekw Nehirowisiw. Even if the negotiations have not resulted in a concrete agreement, the process has at least contributed to mobilising the Indigenous members around their own social project and toward their political affirmation.

\section{Benoit Éthier, École d'études autochtones (School of Indigenous Studies), Université du Québec en Abitibi- Témiscamingue, Val-d'Or, Quebec, Canada. Email: benoit.ethier@uqat.ca.}

Gérald Ottawa, Conseil de la Nation Atikamekw, La Tuque, Quebec, Canada.Email: gottawa@ atikamekwsipi.com.

Christian Coocoo, Conseil de la Nation Atikamekw, LaTuque, Quebec, Canada.Email: ccoocoo@ atikamekwsipi.com.

\section{Notes}

1 According to my information, an agreement in principle between the three levels of government (Atikamekw Nehirowisiw, Canada and Quebec) was close to being signed in the spring of 2018 (just before Quebec's provincial election held in the fall). More recently (23 January 2019), the band council of the community of Opitciwan, one of the three Atikamekw Nehirowisiw communities, decided to withdraw from the negotiation process and bring its claim to court.

2 The term Nehirowisiw (an autonomous person; Nehirowisiwok in its plural form) is the ethnonym that the Atikamekw have always used to designate themselves. In 2006, the Conseil de la Nation Atikamekw Nehirowisiw officially adopted this designation, see Poirier, Jérôme and Société d'histoire Atikamekw Nehirowisiw (2014).

3 Created in 1983, the CNA has the mandate to lead the Comprehensive Land Claims Negotiation and to ensure the application of the political decisions taken during the general assemblies of the Atikamekw Nehirowisiwok representatives of the three communities (Charest 1992). This political authority is a national initiative and therefore is not subject to the Indian Act, unlike band councils.
4 In 2018, for the first time, members of the two other Atikamekw Nehirowisiw communities participated in the Moteskano project.

5 This is a large reservoir created as a result of the dams built downstream of the Saint-Maurice River (Tapiskwan sipi) in 1916 and 1948.

6 An interesting documentary on the Moteskano project (2015 edition) was produced by Jimmy Neilan Clary and Nicolas Awashish from Opitciwan. These young people received the support of the Mahikan Studio of the community youth centre. See Studio Mahikan (2015).

7 See Studio Mahikan (2016) for a public video on the Tapiskwan project.

8 Each year, about 50 participants complete the entire journey, which takes about 12 days. Most participants are between the ages of 15 and 40, but all members of the three communities can participate, regardless of their age. In summer 2016, a couple of seniors over the age of 70 took part in the experience with young people. Note that all the families are directly or indirectly involved in the organisation of the Tapiskwan project (through the preparation of camping sites, equipment, transport of material, moral and financial support and so forth).

9 It should be noted that in the last few years, several Indigenous organisations, including the Petapan Regroupement grouping three Innu communities (Mashteuiatsh, Essipit and Nutashkuan) - have put considerable pressure to repeal the extinction clause (Charest 2017).

10 This department was dissolved in August 2017 and replaced by two new departments: Indigenous Services Canada, and Crown-Indigenous Relations and Northern Affairs Canada.

11 Commonly named Cree, the James Bay Indigenous people identify themselves as Eeyouch (coastal groups) and Eenouch (inland groups).

12 The James Bay and Northern Quebec Native Claims Settlement Act (SC 1976-77, c 32) is commonly referred to as Bill C-9.

13 These amounts should be considered for illustrative purposes only, as they have not been validated.

14 Please note that some information on the results-based approach is no longer accessible on the CIRNAC website. You can find a PDF (in French) scanned from the CIRNAC website (FAQ section) by the Groupe international de travail pour les peuples autochtones (GIPTA 2012).Although some of the information on this approach is no longer available on the internet (due to the dissolution of Indigenous and Northern Affairs Canada and the creation of CIRNAC), nothing explicitly indicates that this approach has been set aside, despite being challenged or questioned by some Indigenous groups.

15 To consider a similar situation with Innu of Petapan group in the context of their land claims negotiation, see Charest (2017).

16 The members of this working group included Nicole Petiquay, Gérald Ottawa, Christian Coocoo and Benoit Éthier. The working group's mandate was to find equivalences between western legal concepts and Atikamekw Nehirowisiw legal concepts. Several other Atikamekw Nehirowisiwok involved in territorial negotiation also participated in the group's fruitful discussions. 


\section{References}

Asch, Michael, (ed.). (1998) 2008. Aboriginal and Treaty Rights in Canada: Essays on Law, Equality, and Respect for Difference. Vancouver: UBC Press.

Asch, Michael, and Norman Zlotkin. 2008. "Affirming Aboriginal Title: A New Basis for Comprehensive Claims Negotiations." In Aboriginal and Treaty Rights in Canada: Essays on Law, Equality, and Respect for Difference, edited by Michael Asch, 208-229. Vancouver: UBC Press.

Atikamekw Nehirowisiw, Innu and Anicinabe Coalition. 2014. Proceedings from the conference of Atikamekw Nehirowisiw, Innu and Anicinabe Coalition to defend their ancestral titles in the convention territory, Montreal, QC, 13 November.

Belrichard, Chantelle. 2019. "Budget 2019: \$1.4B in Loans to Be Forgiven or Reimbursed to Indigenous Groups for Treaty Negotiations.” CBC News, 19 March. https://www.cbc.ca/news/indigenous/ budget-2019-treaty-loans-forgiven-1.5063128.

Blaser, Mario. 2004. "Life Projects: Indigenous Peoples' Agency and Development." In In the Way of Development: Indigenous Peoples, Life Projects and Globalization, edited by Mario Blaser, Harvey A. Feit, and Glenn McRae, 26-44. London: Zed Books.

- 2013. "Ontological Conflicts and the Stories of Peoples in Spite of Europe: Toward a Conversation on Political Ontology." Current Anthropology 54 (5): 547-568. https:// doi.org/10.1086/672270.

Borrows, John. 2010. Canada's Indigenous Constitution. Toronto: University of Toronto Press.

- 2016. Freedom and Indigenous Constitutionalism. Toronto: University of Toronto Press.

Brassard, Denis, and Daniel Castonguay. 1983. Nitaskinan: Recherche sur l'occupation et l'utilisation du territoire. Rapport synthèse. Village-des-Hurons, QC: Conseil Attikamek-Montagnais.

Calder v British Columbia, [1973] 3 SCR 313.

Castonguay, Daniel. 1983. Occupation et utilisation du territoire par les Attikameks de Manouane. Rapport communautaire. Village-des-Hurons, QC: Conseil Attikamek-Montagnais.

Charest, Paul. 1992. "La prise en charge donne-t-elle du pouvoir? Lexemple des Atikamek et des Montagnais." Anthropologie et Sociétés 16 (3): 55-76. https://doi. org/10.7202/015233ar.

- 2001. "The Land Claims Negotiations of the Montagnais, or Innu of the Province of Quebec and the Management of Natural Resources." In Aboriginal Autonomy and Development in Northern Quebec and Labrador, edited by Colin Scott, 255-273. Vancouver: UBC Press.

_. 2017. "De la prise en charge à l'autonomie gouvernementale pour les Innus: Un projet de société réduit et face à de nouveaux obstacles." Les Cahiers $d u$ CIÉRA 14: 8-32.

Clammer, John, Sylvie Poirier, and Eric Schwimmer, (eds.). 2004. Figured Worlds: Ontological Obstacles in Intercultural Relations. Toronto: University of Toronto Press.

Cleary, Bernard. 1993. "Le long et difficile portage d'une négociation territoriale.” Recherches amérindiennes au Québec 27 (1): 49-60.
Conseil Atikamekw-Montagnais (CAM). 1979. "Nishastanan Nitasinan (Notre terre, nous l'aimons et nous y tenons): Revendications territoriales des bandes attikamèques et montagnaises adressées au Ministre des Affaires indiennes et du Nord, Représentant du gouvernement du Canada." Recherches amérindiennes au Québec 9 (3): 171-193.

Conseil de la Nation Atikamekw Nehirowisiw (CNA). 1996. Sommet Aski. 3-5 décembre 1996. La Tuque, QC: Conseil de la Nation Atikamekw Nehirowisiw.

—. 1998. Termes de référence en Atikamekw pour la Commission sur la Constitution Atikamekw. La Tuque, QC: Conseil de la Nation Atikamekw Nehirowisiw.

- 2012. Commission territoriale atikamekw, 29-30 octobre 2012. La Tuque, QC: Conseil de la Nation Atikamekw Nehirowisiw.

—. 2014. Waskamanakotatan kitaskino: Soyons responsagble envers Kitaskino. Colloque sur le territoire. September 28-October 1. Wemotaci, QC: Conseil de la Nation Atikamekw Nehirowisiw.

Crown-Indigenous Relations and Northern Affairs Canada (CIRNAC). 2009. The James Bay and Northern Quebec Agreement and the Northeastern Quebec Agreement 2005-2006 and 2006-2007 Annual Report. Accessed 3 April 2018. http://publications.gc.ca/collections/collection_2010/ ainc-inac/R71-38-2007-eng.pdf.

Crown-Indigenous Relations and Northern Affairs Canada (CIRNAC). 2014a. Renewing the Federal Comprehensive Land Claims Policy. Accessed 23 August 2019. https:/www. reaanc-cirnac.gc.ca/eng/1408631807053/1544123449934\#chp3. - 2014b. Evaluation of the Process of Negotiating Comprehensive Land Claims and Self-Government Agreements - Follow-Up Report Status Update as of December 31, 2014. Accessed 9 August 2020. https://www. rcaanc-cirnac.gc.ca/eng/1490193557683/1538051296234.

- n.d. Fiche d'information - Une approche axée sur les résultats pour la négociation des revendications territoriales globales et de l'autonomie gouvernementale. Accessed 2 November 2016. https://www.aadnc-aandc. gc.ca/fra/1406824128903/1406824211834 (site discontinued).

Dandenault, André. 1983. Occupation et utilisation du territoire par les Attikameks de Weymontachie. Rapport communautaire. Village-des-Hurons, QC: Conseil Atikamekw-Montagnais.

Dupuis, Renée. 1993. "Historique de la négociation sur les revendications territoriales du Conseil des Atikamekw et des Montagnais (1978-1992)." Recherches Amérindiennes au Québec 23 (1): 35-48.

- 1997. Tribus, peuples et nations: Les nouveaux enjeux des revendications autochtones au Canada. Montreal: Boréal.

Éthier, Benoit. 2017. Orocowewin notcimik itatcihowin: Ontologie politique et contemporanéité des responsabilités et des droits territoriaux chez les Atikamekw Nehirowisiwok (Haute-Mauricie, Québec) dans le contexte des négociations territoriales globales. $\mathrm{PhD}$ dissertation, département d'anthropologie, Université Laval.

Éthier, Benoit, and Sylvie Poirier. 2018. "Territorialité et territoires de chasse familiaux chez les Atikamekw Nehirowisiwok dans le contexte contemporain." Anthropologica 60 (1): 106-118. https://doi.org/10.3138/ anth.60.1.t11. 
Feit, Harvey. 2004. "James Bay Crees' Life Projects and Politics: Histories of Place, Animal Partners and Enduring Relationships." In The Way of Development: Indigenous Peoples, Life Projects and Globalization, edited by Mario Blaser, Harvey A. Feit and Glenn McRae, 92-110. London: Zed Books.

Government of Canada. 2019. "Chapter 3: Advancing Reconciliation.” Budget 2019. Accessed 23 August 2019. https://www.budget.gc.ca/2019/docs/plan/chap-03-en.html.

Grammond, Sébastien. 2013. Terms of Coexistence: Indigenous Peoples and Canadian Law. Toronto: Thomson Reuters.

Groupe international de travail pour les peuples autochtones (GIPTA). 2012. Foire aux questions: Une approche axée sur les résultats pour la négociation de traités et de l'autonomie gouvernementale. Accessed 3 April 2018. http://www.gitpa.org/web/AMN\%20CANADA\%20 $\% 20$ Une $\% 20$ approche $\% 20$ axee $\% 20$ sur $\% 201$ es $\% 20$ resultats\%20.pdf.

Harris, Cole. 2004. "How Did Colonialism Dispossess? Comments from an Edge of Empire." Annals of the Association of American Geographers 94 (1): 165-182. https://doi.org/10.1111/j.1467-8306.2004.09401009.x.

Houde, Nicolas. 2011. Experimenting with What Will Become Our Traditions: Adaptive Co-Management as a Bridge to an Atikamekw Nehirowisiw Post-Treaty World in Nitaskinan. PhD dissertation, Department of Geography, McGill University.

—. 2014. "La gouvernance territoriale contemporaine du Nitaskinan: Tradition, adaptation et flexibilité." Recherches Amérindiennes au Québec 44 (1): 23-33. https://doi.org/10.7202/1027877ar.

Léger, Yves. 1983. Occupation et utilisation du territoire par les Attikameks d'Obedjiwan. Rapport communautaire. Village-des-Hurons, QC: Conseil Atikamekw-Montagnais.

Nadasdy, Paul. 2012. "Boundaries among Kin: Sovereignty, the Modern Treaty Process, and the Rise of EthnoTerritorial Nationalism among Yukon First Nations." Comparative Studies in Society and History 54 (3): 499532. https://doi.org/10.1017/S0010417512000217.

— 2018. Sovereignty's Entailments: First Nation State Formation in the Yukon. Toronto: University of Toronto Press.

Ortner, Sherry. 1995. "Resistance and the Problem of Ethnographic Refusal." Society for Comparative Study of Society and History 37 (1): 173-193. https://doi. org/10.1017/S0010417500019587.

Pasternak, Shiri. 2017. Grounded Authority: The Algonquins of Barriere Lake against the State. Minneapolis: University of Minnesota Press.

Poirier, Sylvie. 2000. "Contemporanéité autochtones, territoires et (post)colonialisme: Réflexions sur des exemples canadiens et australiens." Anthropologie et Sociétés 24 (1): 137-153. https://doi.org/10.7202/015640ar.

— 2004. "The Atikamekw: Reflections on Their Changing World." In Native Peoples: The Canadian Experience, edited by Bruce R. Morrison and Roderick Wilson, 129149. Oxford: Oxford University Press.

- 2010. "Change, Resistance, Accommodation and Engagement in Indigenous Contexts: A Comparative
(Canada-Australia) Perspectives." Anthropological Forum 20 (1): 41-60. https://doi.org/10.1080/00664670903524202.

—. 2013. "The Dynamic Reproduction of Hunter-

Gatherers' Ontologies and Values." In Companion to the Anthropology of Religion, edited by Janice Boddy and Michael Lambeck, 50-68. Malden, MA: Wiley-Blackwell. _. 2017. "Nehirowisiw Territoriality: Negotiating and Managing Entanglement and Coexistence.” In Entangled Territorialities: Negotiating Indigenous Lands in Canada and Australia, edited by Françoise Dussart and Sylvie Poirier, 212-234. Toronto: University of Toronto Press.

Poirier, Sylvie, Laurent Jérôme and Société d'histoire Atikamekw Nehirowisiw. 2014. "Présentation. Les Atikamekw Nehirowisiwok: Territorialités et savoirs." Recherches Amérindiennes au Québec 64 (1): 3-10. https:// doi.org/10.7202/1027875ar.

Poirier, Sylvie, and Jean-Marc Niquay. 1997-99. Entrevues réalisées dans les communautés de Manawan, d'Opitciwan et de Wemotaci. Traduit et transcrit par Jean-Marc Niquay. La Tuque, QC: Conseil de la Nation Atikamekw.

Povinelli, Elizabeth A. 2002. The Cunning of Recognition. Durham, NC: Duke University Press.

Sahlins, Marshall. 1999. "What Is Anthropological Enlightenment? Some Lessons of the Twentieth Century." Annual Review of Anthropology 28: i-xxiii. https://doi. org/10.1146/annurev.anthro.28.1.0.

Samson, Colin. 1999. "The Dispossession of the Innu and the Colonial Magic of Canadian Liberalism." Citizenship Studies 3 (1): 5-25. https://doi. org/10.1080/13621029908420698.

_ 2016. "Canada's Strategy of Dispossession: Aboriginal Land and Rights Cessions in Comprehensive Land Claims." Canadian Journal of Law and Society/Revue Canadienne Droit et Société 31 (1): 87-110. https://doi. org/10.1017/cls.2016.2.

Scott, Colin. 2017. "The Endurance of Relational Ontology: Encounters between Eeyouch and Sport Hunters." In Entangled Territorialities: Negotiating Indigenous Lands in Canada and Australia, edited by Françoise Dussart and Sylvie Poirier, 51-69. Toronto: University of Toronto Press.

Sioui, Marie-Michèle. 2014. Des autochtones veulent renégocier la Convention de la Baie-James. La Presse, 13 November. http:/www.lapresse.ca/actualites/ politique/politique-quebecoise/201411/13/01-4818477-desautochtones-veulent-renegocier-la-convention-de-la-baiejames.php (accessed 5 August 2020).

Sletto, Bjorn. 2009. “'Indigenous People Don't Have Boundaries': Reborderings, Fire Management, and Productions of Authenticities in Indigenous Landscapes." Cultural Geographies 16 (2): 253-277. https://doi. org/10.1177/1474474008101519.

St-Pierre, Caroline. 2014. Convention de la Baie-James: Une coalition pour la défense des titres ancestraux. $L a$ Presse, 13 November. http:/www.lapresse.ca/actualites/ National/201411/13/01-4818686-convention-de-la-baiejames-une-coalition-pour-la-defense-des-titres-ancestraux. php (accessed 5 August 2020).

Studio Mahikan. 2015. "Moteskano.” Accessed 5 August 2020. https:/www.youtube.com/watch?feature=youtu. be\&v =Lz6NBo_QPRg\&app=desktop. 
_. 2016. "Tapiskwan Sipi." Accessed 5 August 2020. https:// www.youtube.com/watch?v=DFyhxR7fr7o.

Thom, Brian. 2009. "The Paradox of Boundaries in Coast Salish Territories.” Cultural Geographies 16 (2): 179-205. https://doi.org/10.1177/1474474008101516.

- 2014. "Reframing Indigenous Territories: Private Property, Human Rights and Overlapping Claims." American Indian Culture and Research Journal 38 (4): 3-28. https://doi.org/10.17953/aicr.38.4.6372163053512w6x. - 2015. "Confusion sur les territoires autochtones au Canada.” In Terres, territoires, ressources: Politiques, pratiques et droits des peuples autochtones, edited by Irène Bellier, 89-105. Paris: L'Harmattan.

Tully, James. 2016. "Deparochializing Political Theory and Beyond: A Dialogue Approach to Comparative Political Thought." Journal of World Philosophies 1: 51-74.

Vincent, Sylvie. 2016.“'Chevauchements' territoriaux: $\mathrm{Ou}$ comment l'ignorance du droit coutumier algonquins permet de créer de faux problèmes." Recherches Amérindiennes au Québec 46 (2-3): 91-103. https://doi. org/10.7202/1040438ar. 